\title{
Samba da Vela: o samba como tradução de uma realidade
}

\author{
Samba da vela: samba as a translation of the reality
}

\section{Aretha Bley Pestana *}

\begin{abstract}
Resumo:
O presente trabalho teve como objetivo compreender a importância do Samba da Vela, roda de samba praticada em Santo Amaro (São Paulo), enquanto manifestação cultural e expressão social na constituição da cidadania. As pesquisas, bibliográfica e de campo, apontaram para a configuração do samba e do Samba da Vela para além do divertimento, isto é, como expressão das camadas populares pela transformação social.
\end{abstract}

Palavras-chave: samba; Samba da Vela; cidadania; resistência sociocultural.

\begin{abstract}
:
This paper aims at the comprehension of the importance of the Samba da Vela, a "roda de samba" in Santo Amaro (São Paulo), as a cultural manifest and social expression on the citizenship constitution. The bibliographic and field researches pointed that the samba and Samba da Vela original meaning goes beyond entertainment, that is, as an expression of the popular layers for the social transformation.
\end{abstract}

Keywords: samba, Samba da Vela, citizenship, socio-cultural resistance.

\begin{abstract}
"Não sou apenas objeto da História, mas seu sujeito igualmente. No mundo da História, da cultura, da política, constato não para me adaptar, mas para mudar [...]"
\end{abstract}

Paulo Freire

\section{Introdução}

Para não fazer um discurso raso, baseado apenas no senso comum, é essencial refletir sobre a atual conjuntura. Vivenciamos a mercantilização das relações sociais, a defesa do estado mínimo e a priorização do econômico em detrimento do social. Somos uma sociedade invadida pelo consumo que, segundo Maria Lúcia Martinelli (1998, p. 142), segue "desaprendendo como desfrutar do lúdico e abrindo mão do prazer, e uma sociedade que abre mão do prazer está fadada a perecer."

\footnotetext{
${ }^{*}$ Graduada em Serviço Social pela UniFMU e em Letras pela USP. Assistente social do Instituto Israelita de Responsabilidade Social. E-mail: arethabley@hotmail.com
} 
A cultura e suas diversas manifestações podem ser definidas como instrumento de exclusão social ou de luta das camadas populares pela consolidação da cidadania. Exemplo de resistência e luta é o objeto da presente pesquisa - Samba da Vela - roda de samba realizada na Casa de Cultura de Santo Amaro (Casa de Cultura Manoel Cardoso de Mendonça), toda segunda-feira, cujo objetivo é apresentar composições diretamente ao público, com o intuito de revelar novos compositores e refletir sobre a realidade em que estão inseridos os participantes.

O samba, nesta pesquisa, foi estudado a partir de um enfoque antropológico e sociológico, da mesma maneira que lêda Marques Britto (1986) o defende. É neste sentido que a autora caracteriza o samba, ou seja, como um exercício de resistência dos negros migrantes das áreas rurais do Estado de São Paulo para os bairros pobres da capital, em face à opressão política de quem detinha o poder. Exercício este que data da virada do século XIX para o XX e que, com características um pouco distintas, permanece na atualidade.

Muniz Sodré (apud MOURA, 2004, p. 41) reitera essa perspectiva ao explicar que "é no interior desses lugares paralelos (referindo-se às rodas de samba) que o samba pode ainda constituir-se numa prática de resistência cultural negro-popular."

A análise da cultura, numa perspectiva ampliada, e do samba, como uma forma de expressão das camadas populares, instiga-nos a pensar como uma roda de samba - Samba da Vela - pode representar uma prática cultural de luta e/ou de ressignificação do que está posto pela sociedade atual.

Para realizar a pesquisa de campo, foram entrevistados três dos quatro fundadores e um dos músicos do Samba da Vela, e aplicados vinte questionários, dos quais, cinco foram respondidos pelos músicos dessa roda de samba e quinze por seus frequentadores.

\section{O Samba pede passagem na Cultura Brasileira}

Ao iniciar a pesquisa sobre o Samba da Vela enquanto expressão social e manifestação cultural, percebemos a importância de discutir o conceito de cultura e suas implicações para o presente estudo.

No entanto, definir cultura, conceitualmente, é uma tarefa difícil de ser realizada. Segundo os autores com os quais trabalhamos e, a partir das entrevistas e questionários 
aplicados, isso acontece, especialmente, pela amplitude teórica do conceito e em decorrência de suas distintas possibilidades de abordagem. Como exemplo, na pesquisa de campo, apareceram nove definições para a palavra.

\section{Gráfico 1: Conceito de Cultura}

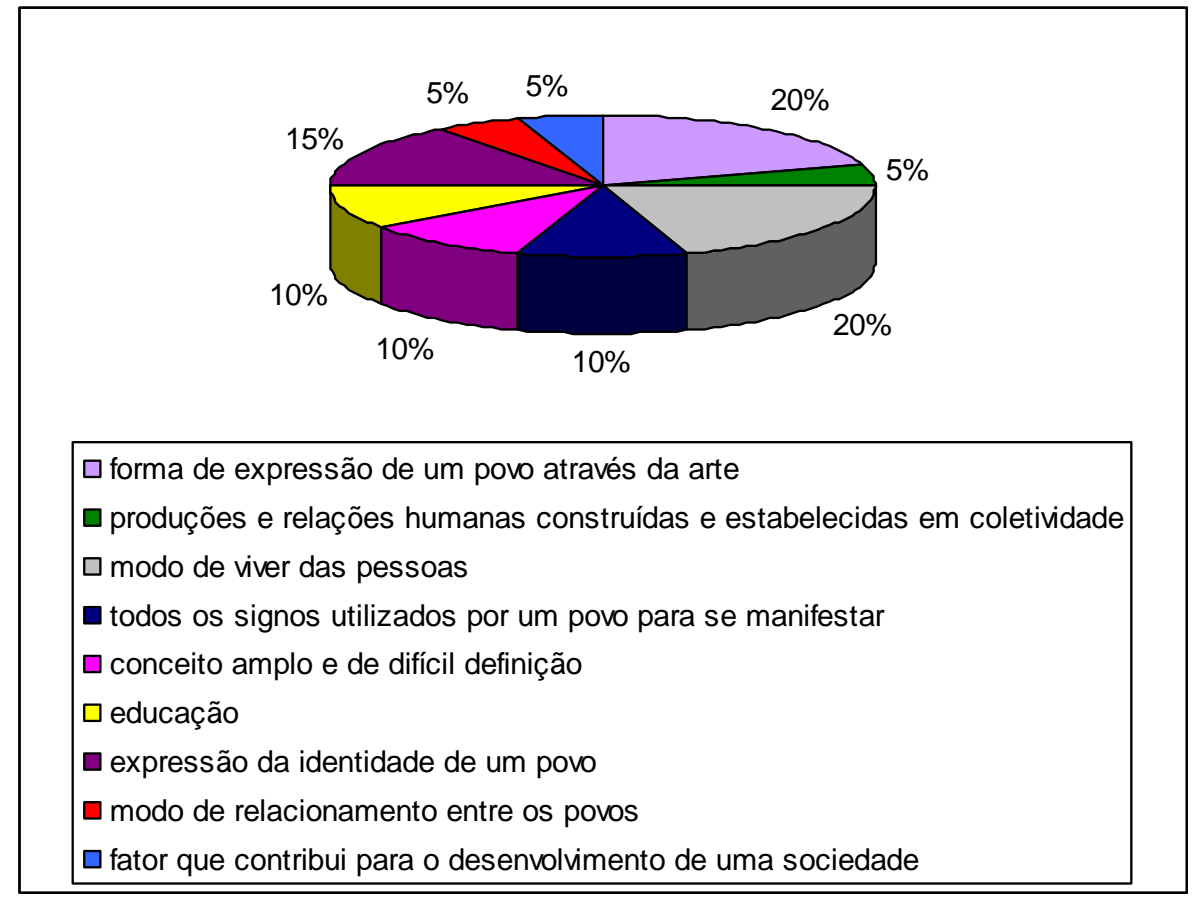

Fonte: Gráfico formulado a partir dos questionários aplicados entre 10/2008 e 01/2009

A partir do gráfico, mesmo considerando expressões que vinculam cultura à educação, à arte e ao desenvolvimento da sociedade, são predominantes os sentidos que a relacionam ao povo, às interações humanas, aos modos de vida, à identidade ${ }^{1}$ popular $\mathrm{e}$ à coletividade.

Desse modo, evidencia-se que diversas são as definições de cultura. Destacamos a de Gramsci, trabalhada por Maria Fernanda Madríz (1989):

Gramsci parte dos conceitos elitistas que definem cultura como saber enciclopédico, atividade especulativa reservada aos grandes talentos e circunscrita ao campo artístico e educativo. A partir daí, constrói um conceito dinâmico e historicista, no qual a cultura é compreendida como um processo que

${ }^{1}$ Cuche (2002) explica que a identidade "permite que o indivíduo se localize em um sistema social e seja localizado socialmente." (p. 177). Além disso, destaca a necessidade de considerarmos a concepção dinâmica da identidade, uma vez que esta "se constrói e se reconstrói constantemente no interior das trocas sociais" (p. 178). 
se conserva e se renova, permanentemente, na prática social. Esta ótica amplia o sujeito produtor/receptor/consumidor de cultura a todo o universo social. (apud FERREIRA, 1997, p. 29).

Portanto, compreendemos e utilizamos o conceito de cultura como todo processo humano que se constrói na prática social. Não somente uma manifestação artística, mas todas as manifestações do homem, ou seja, um conjunto de valores, símbolos, crenças, memória, práticas cotidianas, alimentação, habitação, modos de pensar, discutir e agir. Também um direito de todos os cidadãos, como descrito na Constituição Federal e na Declaração dos Direitos Humanos.

Da mesma forma, entendemos o samba não somente como um gênero musical e artístico, mas, como explica Moura (2004), a expressão cultural de uma comunidade e um exemplo de "fato social total" (conceito utilizado por Marcel Mauss ${ }^{2}$ ), uma vez que carrega sentidos religiosos, econômicos, políticos, sociais, morais, estéticos e ideológicos.

Contudo, comumente, são encontradas definições que privilegiam a dimensão artística do samba e destacam os instrumentos e a dança. Moura reforça esta análise explicando que, de forma genérica, entende-se o samba como:

[...] um gênero musical de compasso binário, em dois por quatro (quando executado por brasileiros), de andamento variado, derivado de influências da polca, do maxixe, do lundu, da habanera e do tango 'como aproveitamento consciente das possibilidades dos estribilhos cantados ao som de palmas e ritmo batucado, e os quais seriam acrescentados uma ou mais partes, ou estâncias, de versos declaratórios (MOURA, 2004, p. 34).

Tais significados, ainda que válidos, estão aquém do sentido adotado no projeto que então se desenvolve, posto que reduzem o samba a uma manifestação artística homogênea, como se esta acontecesse da mesma maneira em todos os espaços em que se manifesta. Assim, concordamos com Moura que o conjunto de experiências, sentimentos e vivências faz do samba uma forma de expressão que ultrapassa os limites musicais. 0 samba:

[...] é simultaneamente reunião social, apresentação coreográfica, exercício lúdico de criação e improviso de versos, espaço de ouvir e cantar, de comer e beber, de interação, enfim. [...] Embora ligado ao prazer e ao divertimento, o

2 Marcel Mauss (1872-1950), sobrinho de Émile Durkheim, nasceu em Épinal, França. Sociólogo e antropólogo, foi considerado um dos fundadores da antropologia francesa. Em "Ensaio sobre a dádiva" (1924), uma de suas mais conhecidas obras, define o "fato social total". 
samba forma valores, estabelece normas de conduta e referências comportamentais (MOURA, 2004, p. 68).

Esta concepção se aproxima de nossa compreensão de cultura e aparece entre os resultados dos questionários nas indagações relacionadas ao samba, conforme o gráfico a seguir:

Gráfico 2: Definição e Importância do Samba

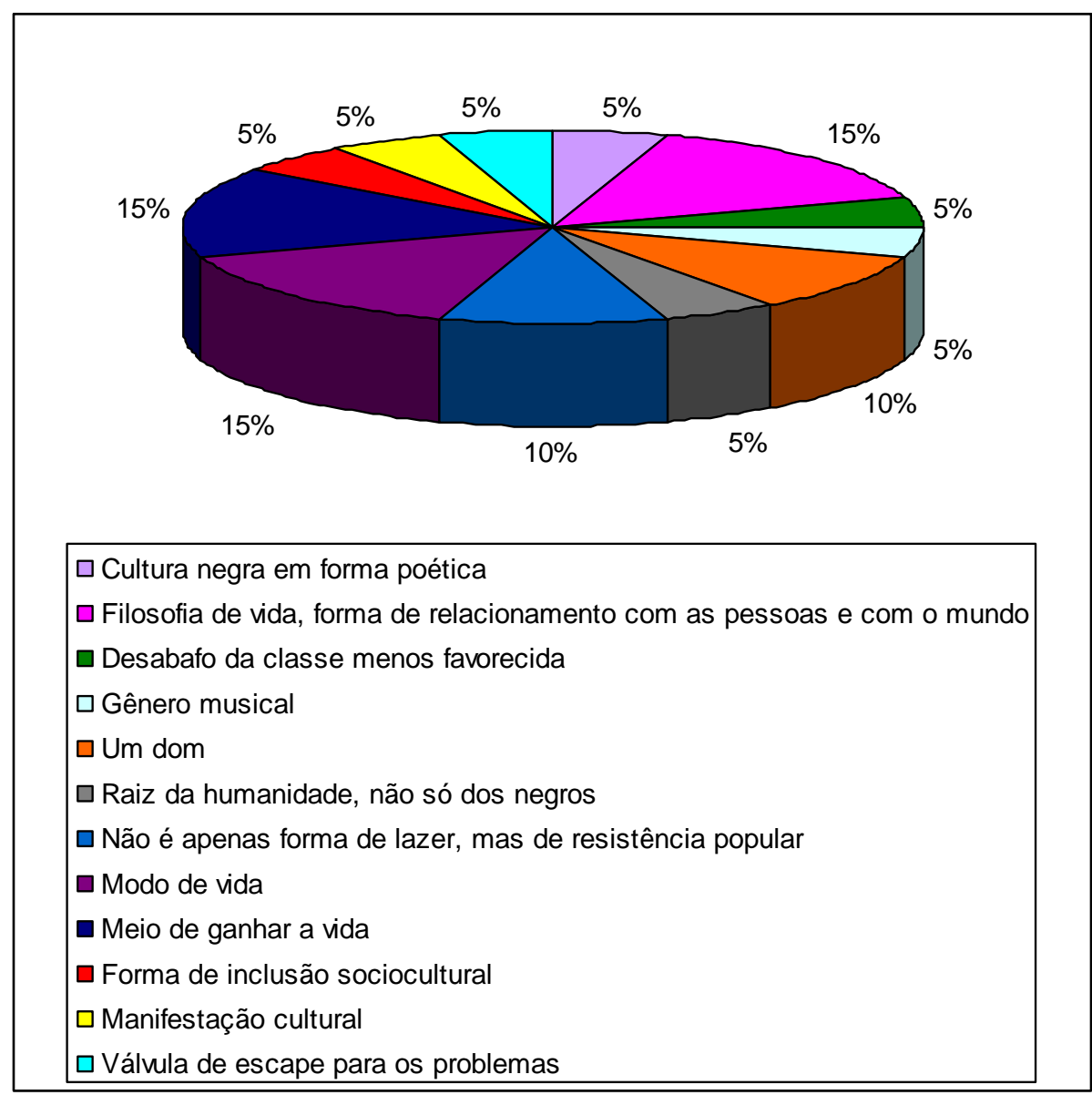

Fonte: Gráfico formulado a partir dos questionários aplicados entre 10/2008 e 01/2009.

A maioria dos entrevistados (95\%) relaciona o samba ao modo de vida, à tradição e à resistência, ou seja, considera-o mais que um simples gênero musical. Maurílio de Oliveira Souza, um dos fundadores do Samba da Vela, assinala que o samba é:

[...] estilo de vida, é esperança de vida...é tudo muito mais. É um gênero em que a gente consegue unir as pessoas, independente da raça, da cor, da idade, da classe social...independente disso. Então, é bom que a gente, pô, eu fiz tantos amigos no samba, amigos de verdade mesmo e eu acredito que muitas pessoas também fizeram. [...] O samba é um ritmo que vem de pessoas pobres, de 
pessoas que, simbolicamente, estão sempre juntas...tem que estar juntas, senão não anda, não vai pra frente. E aí acontece de, no momento de alegria, no momento como esse do Samba da Vela, vai tá junto, independente...juntos para plantar e juntos para colher também (MAURÍLIO, 09/01/2009).

Para alguns, o samba expressa a própria vida, o que é perceptível nas falas de Chapinha e Paqüera, também fundadores do Samba da Vela: "se não fosse o samba, eu não sei o que eu estaria fazendo da vida. [...] O samba é tudo pra mim." (CHAPINHA, 09/01/2009).

Pra mim é tudo! [...] O samba pra mim é uma forma de linguagem, é uma forma de comunicação, é uma forma de expressão. Ele conta o meu dia, ele conta a minha sorte, ele conta tudo. Sei lá, sem o samba eu não teria personalidade, como muito jovem que fica assumindo a personalidade de outros países, o modo de vestir, a forma de linguagem, o jeito de se comunicar. Pra mim, o samba é a minha identidade como brasileiro (PAQÜERA, 20/04/2009).

Muitos autores, dentre eles, Nei Lopes (2005), Napolitano (2007), Moura (2004), Marcelino (2007) e Sodré (1998), defendem a ideia de que o samba tem origem e identidade negras, pois nasceu da influência de ritmos africanos.

Segundo Nei Lopes (2005), a cultura brasileira, especialmente, no âmbito da música, está estruturada em matrizes africanas conguesas e iorubanas. De acordo com o sambista e pesquisador de nossa música popular, nos primeiros anos da colonização, as congadas, influenciadas pelas procissões católicas do Brasil colonial e imperial, constituíram o início dos maracatus, dos ranchos de reis e escolas de samba.

Conforme Márcio M. Marcelino:

[...] de utilização muito abrangente, o termo samba é originário da palavra 'semba' em quimbundo (língua de indígenas bantos de Angola) que designa 'umbigo', ou seja, um gesto coreográfico quase que onipresente na expressão de 'umbigadas'. Simbolizando primeiro a dança, para anos mais tarde se transformar em composição musical, o samba foi também chamado de batuque, dança de roda, lundu, chula, maxixe, batucada e partido alto, entre outros, muitos deles convivendo simultaneamente (Andrade, 1965. p.148-52), afinal, havia uma miscelânea musical na época (final do século XIX, início do século XX), sobretudo na época dos carnavais, gerando assim uma influência de diversos tipos musicais para sua formação (MARCELINO, 2007, p. 13).

Sodré (1998, p. 12) explica que, historicamente, onde estivesse o negro, no campo ou na cidade, ali havia samba, o que evidencia uma íntima ligação entre os dois e confirma o samba como forma de resistência "ao imperativo social (escravagista) de redução do 
corpo negro a uma máquina produtiva e como uma afirmação da continuidade do universo cultural africano."

No entanto, há autores, como Bernardo Alves, que defendem a ideia de que o samba não é de origem negra, mas indígena, e já existia no Brasil antes mesmo da chegada dos negros à América. Segundo ele, na língua tupi, samba significa "dança de roda". Em seu livro "A Pré-história do samba" (2002), o autor afirma que a verdadeira história do samba foi abafada, negando, assim, suas raízes étnicas e antropológicas. Foi, segundo ele, essa história inventada que elegeu "Pelo Telefone" como o primeiro samba, a casa da Tia Ciata como berço do samba e Sinhô como o rei do samba.

Das leituras realizadas para a elaboração deste trabalho, outra polêmica aparece no que diz respeito ao local de surgimento do samba no Brasil. Alguns estudiosos acreditam, assim como cantava Vinícius de Moraes, que "o samba nasceu lá na Bahia". Neste contexto, teria começado como dança de roda originada em Angola e trazida, no período colonial, para a Bahia, pelos escravos.

O samba de roda está presente, ainda hoje, em todo o estado da Bahia, especialmente, na região do Recôncavo Baiano, tendo seu primeiro registro sido feito em 1860. Desde os primeiros registros, "já se testemunha a ligação do samba de roda a tradições culturais transmitidas por africanos escravizados e seus descendentes. Tais tradições incluem, entre outros, o culto aos orixás e caboclos, o jogo da capoeira e a chamada comida de azeite" (SOCIEDADE AMIGOS DA CULTURA AFRO-BRASILEIRA). ${ }^{3}$

Outros autores afirmam ser o samba natural do Rio de Janeiro e que seu início teria ali se dado após o declínio da produção do café e a abolição da escravatura, quando os negros se deslocaram para a então capital do país.

Entretanto, não é nossa intenção buscar uma resposta para a origem do samba. Decidimos somente mencionar os debates existentes para não nos afastarmos do eixo principal de nossa pesquisa. Por questões históricas, políticas e econômicas, o samba carioca passou a ser considerado de maior relevância. No entanto, pensamos que o samba é legítimo em todo lugar.

De acordo com Tinhorão (2005), após a Abolição da Escravatura, em 1888, os trabalhadores negros começaram a migrar do campo para a cidade, e o Rio de Janeiro, no

\footnotetext{
${ }^{3}$ Site identificado nas referências bibliográficas.
} 
fim do século XIX, transformou-se no ponto de reunião dos migrantes internos. Migrantes estes que, em grande parte, eram ex-escravos e trabalhadores do campo, muitos deles, nordestinos, especialmente, baianos, antes levados para o Vale do Paraíba com a expansão da cultura do café. Também se dirigiram para o Rio de Janeiro pessoas que fugiam das lutas e revoltas locais, bem como, seus combatentes, constituindo o ambiente social e urbano da cidade.

Naquele contexto, os que faziam parte das camadas mais pobres, isto é, ex-escravos, trabalhadores não qualificados, biscateiros etc., passaram a criar, nas cidades, suas próprias formas de sobrevivência física e cultural. "Seria entre tais comunidades que iriam surgir no Rio as duas maiores criações coletivas do povo miúdo no Brasil: o carnaval de rua dos ranchos e suas marchas, e o ritmo do samba" (2005, p. 264).

Ainda conforme o autor, "qualquer grupo reunido para cantar e fazer figurações de dança ao ar livre, ao som de palmas, atabaques e pandeiros, era por princípio enquadrado como incurso nas disposições contra a malandragem e a capoeiragem" (2005, p. 275). Situação muito bem ilustrada na letra da música "Delegado Chico Palha", de Hélio e Campolino:

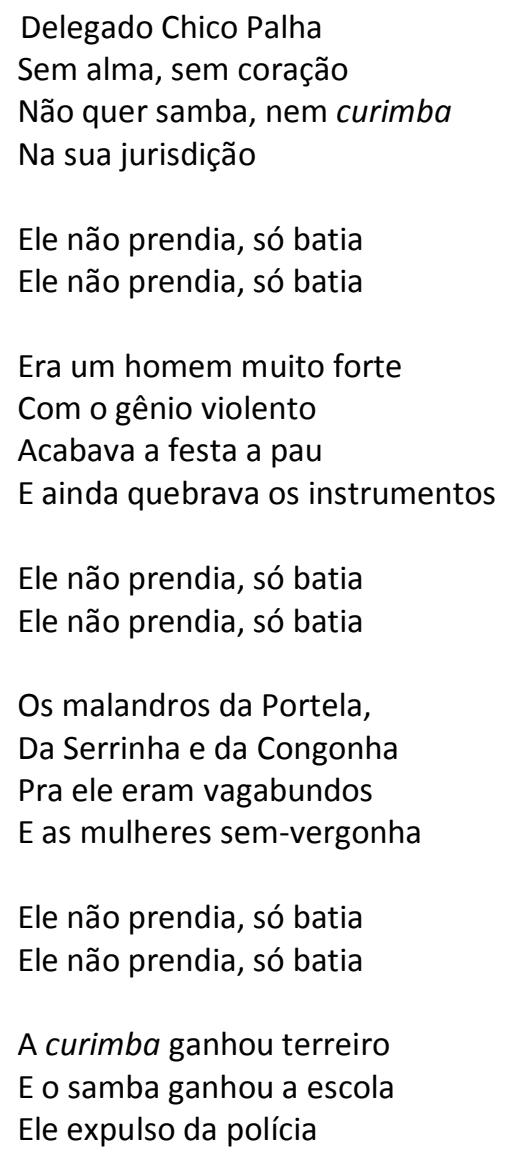


Vivia pedindo esmola

Ele não prendia, só batia

Ele não prendia, só batia

Foi estabelecida, desde a I República, a perseguição contra as rodas de batuque, e o local mais seguro para as reuniões das pessoas das comunidades mais pobres passou a ser a casa das famílias baianas, como a da Tia Prisciliana (Perciliana Maria Constança, mãe de João da Baiana), da Tia Amélia (Amélia Silvana de Araújo, mãe de Donga) e da Tia Ciata (Hilária Batista de Almeida). Em 1917, é gravado o primeiro samba, "Pelo Telefone”, música de Donga, que teria sido produto de uma criação coletiva numa roda de partido alto, da qual também participaram Mauro de Almeida e Sinhô.

A casa da Tia Ciata, na Praça Onze, segundo Sodré (1998, p. 15), foi um dos lugares mais importantes de resistência musical à ideia de marginalização erguida contra o negro após a Abolição da Escravatura. "Na sala de visitas, realizavam-se bailes (polcas, lundus, etc,); na parte dos fundos, samba de partido-alto ou samba-raiado; no terreiro, batucada."

Logo, o samba, desde suas origens, não se configurava apenas como uma expressão musical ou dança, mas como um instrumento de resistência sociocultural, tanto dos negros quanto daquele grupo social marginalizado da vida urbana carioca e brasileira.

Contudo, como destaca Tinhorão (2005), não há como ignorar que a iniciativa de registro do samba "Pelo Telefone", na Seção de Direitos Autorais da Biblioteca Nacional do Rio de Janeiro, revela o início do processo de profissionalização dos sambistas oriundos das camadas populares e a transformação do samba em mercadoria.

A partir da década de 1930, especialmente, no Estado Novo de Getúlio Vargas, o Estado brasileiro também buscou atuar e modelar o samba conforme seus interesses, na formação da chamada identidade brasileira e de sua cultura popular. Para Bryan McCann (2004), há:

[...] três estágios da relação entre samba e identidade nacional: o primeiro situado entre 1930 e 1937, com o surgimento e a consolidação da percepção da relação entre samba e identidade nacional, com várias visões e projetos informando esta percepção geral. O segundo, entre 1937 e 1945, marcado pelo estreitamento semântico do campo do samba como expressão da nação. Nesta fase, o Estado varguista chegou a assimilar o samba cívico, de exaltação solene e folclórica da nação, que dividia o mercado musical com outros gêneros musicais e formas de samba. Finalmente, entre 1945 e 1955, houve o retorno de um 
'samba crítico', no seio do qual os compositores assumiam o simbolismo convencional que ligava o 'samba' à 'brasilidade', não para exaltar a pátria, mas para expor as contradições da sociedade brasileira no processo de modernização capitalista, criticando a falência do projeto de 'democracia social e racial' do Estado Novo. (apud NAPOLITANO, 2007, p. 23).

McCann reflete sobre qual seria o lugar do samba e como este pode ser nacional e, ao mesmo tempo, proteger-se da descaracterização sociocultural. Esse dilema é elemento constituinte da tradição do samba e, segundo o autor:

A experiência social e musical do samba, à medida que o gênero foi alçado à condição de música brasileira por excelência, remete-nos a uma vivência coletiva, comunitária, e a um atavismo étnico, cujas origens encontram-se na experiência da senzala, mas também projeta-se sobre a modernidade urbana e a sociedade capitalista (NAPOLITANO, 2007, p. 21).

Assim, além de manifestação artística, o samba é compreendido, neste estudo, como uma das mais significativas expressões socioculturais do povo brasileiro, constituindo a chamada brasilidade: um campo simbólico que permite acompanhar a experiência social e cultural de uma grande parcela da população, de modo a apreender as contradições e desigualdades sociais, bem como, as formas de interação da população, elementos fundamentais para a compreensão da questão social.

\section{A importância da roda de samba}

O samba, embora conhecido como fator de identidade nacional, acontece das mais diferentes maneiras nos locais em que é vivido. Cada região e cada intérprete ou compositor imprime ao samba uma característica particular. Concordamos com Sodré (1998, p. 35) quando afirma ser inconsistente a divisão do samba em vários tipos, pois estes "se baseiam em aspectos técnicos, setoriais (detalhes morfológicos, variações de compassos, etc), esquecendo o lugar da forma musical no quadro complexo de uma cultura." Nesse mesmo sentido, Marcelino (2007, p. 13) explica que "o samba não possui uma única faceta. Na verdade, constitui-se de matizes, com tipos variados, que obtêm certas características que dão ao termo 'samba' um sem fim de tipos e maneiras de ser representado."

Porém, independentemente da existência de vários estilos de samba, importa-nos, neste momento, perceber o papel e a importância da roda de samba. 
Moura (2004) defende a ideia de que a roda de samba é o ambiente onde o sambista se sente verdadeiramente em casa, o que permitiu o desenvolvimento desse tipo de samba como gênero que antecede o samba e a escola de samba. $\mathrm{O}$ autor define a roda como o "resultado da dialética entre o cotidiano e a utopia".

Napolitano e Wasserrman definem o papel da roda de samba, utilizando o livro $\mathrm{Na}$ roda de samba, de Francisco Guimarães, publicado em 1933:

[...] delimitava um lugar social para o samba que fosse, ao mesmo tempo, garantia de uma marca estética indelével: o 'morro' surge como um território mítico, lugar da 'roda' onde se praticava o 'verdadeiro' samba. [...] A imagem da 'roda de samba' voltaria à cena musical em vários momentos da história da música brasileira, sempre utilizada como imagem crítica à industrialização e à individualização da criação e audição musicais. A 'roda de samba' seria o lugar de uma fala musical coletiva, 'pura', 'espontânea', onde a criatividade daquele grupo social que estaria na origem do samba, era recolocada, quase com um rito de origem (NAPOLITANO; WASSERMAN, 2000, p. 3).

De acordo com Pereira (1995 apud MOURA, 2004, p. 35), a roda é um "ritual de encontro, momento de reforço de laços de identidade e de reciprocidade, encontro de iguais e, ao mesmo tempo, lócus de trocas com outros grupos sociais."

A roda de samba, portanto, pode ser compreendida como espaço da coletividade que resiste em meio à sociedade individualista e consumista em que vivemos. Há, em seu seio, as heterogeneidades e as contradições presentes em qualquer grupo, porém, tratase de um ambiente que produz, segundo Moura (2004, p.35), "o efeito de convivência, pertencimento, criação e manutenção de valores, afinidade com a comunidade a que pertence", com base na música, dança, lazer, divertimento e pensamento crítico sobre a realidade. Entendemos o Samba da Vela nesse contexto.

De acordo com as leituras realizadas e com a observação em relação à forma de organização do Samba da Vela, podemos afirmar que há diversas maneiras de um indivíduo ser aceito na roda, sendo a mais natural cantar e tocar. Há, porém, aqueles que ficam no coro e nas palmas e, ainda, os que ficam na cozinha, responsáveis pela comida, costumeiramente, servida nas rodas de samba.

Chapinha e Maurílio, fundadores do Samba da Vela, explicam que o mesmo ali acontece: "Quem toca, toca, quem canta, canta, quem dança, dança e quem só sabe ouvir, ouve..." (CHAPINHA, 19/01/2009). "Todo movimento dos antigos, de samba, tinha a 
comida. Tem umas escolas de samba que sempre serviram comida, na casa do Candeia sempre serviam comida. A gente trouxe pra cá, pros tempos de hoje. Fica tão legal, né? Um ato de solidariedade" (MAURILIO, 19/01/2009).

Conforme Sodré (1998, p. 56), no samba, "produção se distancia do consumo, música não se separa de dança, corpo não está longe de alma, a boca não está suprimida do espaço onde se acha o ouvido." Para Moura (2004, p.115), a roda de samba, portanto, "seria o espaço mítico de construção da cidadania" que "acaba se convertendo em evento de indiscutível caráter político", definição com a qual concordamos.

\section{Samba da Vela: histórias e rituais}

A Casa de Cultura de Santo Amaro (Casa de Cultura Manoel Cardoso de Mendonça) recebe a comunidade do Samba da Vela todas as segundas-feiras. Em média, 250 pessoas participam dessa roda de samba paulistana.

De acordo com Maurílio (MAURíLIO, 19/01/2009), "aquele que procura entender o movimento, difundir, ajudar a difundir, esse, pra mim, é um membro do Samba da Vela. [...] São pessoas que entendem a filosofia, sabem a importância do movimento." Para seus idealizadores, o samba não é apenas um gênero musical, mas um meio/instrumento de formação de ideias. O movimento cultural que fundaram tem o objetivo de:

[...] apresentar as obras diretamente ao público, revelando, transformando, refletindo e promovendo o resgate da cidadania, cultura e lazer, incluindo o cidadão no ambiente das artes, em geral, revitalizando sua autoestima através da música, inserindo-o na sociedade brasileira (SAMBA DA VELA, 2008). ${ }^{4}$

A partir das respostas apresentadas nos questionários, relativas à definição e à importância do Samba da Vela, observamos que muitos de seus participantes o percebem como um "movimento cultural de nosso país" e "manifestação de cultura popular". Além disso, definem o Samba da Vela como um espaço de encontro, troca, democracia, resistência e tradição, conforme gráfico a seguir:

\footnotetext{
4 Site identificado nas referências bibliográficas.
} 


\section{Gráfico 3: Definição e importância do Samba da Vela}

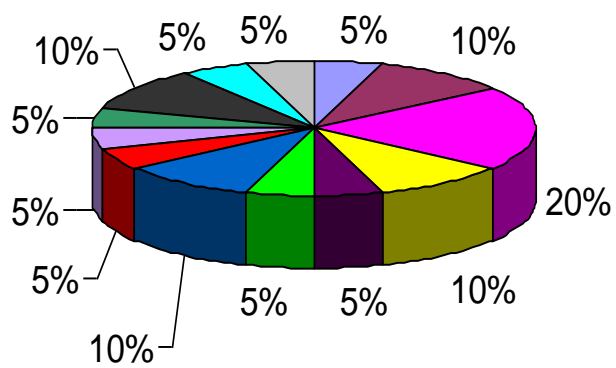

$\square$ Celeiro de talentos

ธ Movimento de samba mais importante de São Paulo e um dos mais importantes do Brasil

$\square$ Movimento cultural de nosso país

$\square$ Manifestação de cultura popular

- Maneira de mostra à comunidade que é possível realizar eventos com qualidade e comprometimento

c Lugar em que se exercita a coletividade pela expressão artístico-musical que é o samba

口Encontro/Reunião de pessoas que gostam de samba

$\square$ Reduto de resistência e exemplo de cultura popular

$\square$ Iniciativa cultural de manter acesa a chama do autêntico samba e meio de motivar as gerações seguintes a dar continuidade à tradição

$\square$ Melhor coisa que aconteceu nos últimos tempos

Maior movimento de compositores de samba do Brasil

$\square$ Espaço democrático de encontro de diferentes pessoas que estão ligadas pelo samba

¿Uma comunidade que sabe afinar sua forma de expressão pelo samba

Fonte: Gráfico formulado a partir dos questionários aplicados entre 10/2008 e 01/2009

O Samba da Vela tem esse nome porque uma vela comanda o tempo do samba. A roda começa quando a vela é acesa e todos cantam o samba "Acendeu a vela", de Paqüera e Edvaldo Galdino. Até que a chama se apague, pessoas de diferentes crenças, idades e classes sociais cantam e apresentam suas criações.

"O esquema da roda pode assustar os mais desavisados", segundo Valente (2003), pois "trata-se de um verdadeiro culto ao samba." Júnior (09/11/2008), um dos músicos da roda, diz: "Eu vou para o pagode para beber, trocar uma idéia. Mas, lá (referindo-se ao Samba da Vela) é uma parada que você vai para escutar, refletir..."

A história dessa manifestação da cultura popular começou em 2000, no bar Ziriguidum, cujo proprietário era o Chapinha. Ele fala sobre o início de tudo:

Eu montei um bar na rua Dr. Antonio Bento porque em 2000 não tinha espaço pra fazer uma roda de samba, né? Samba propriamente dito.[...] Principalmente aqui na zona sul, não tinha onde você fazer um bom samba...montei esse bar e 
começamos a fazer samba. [...] O Paqüera aparecia sempre lá pra brincar na roda de samba e tal, aí o Magno e o Maurílio também apareceram. E eu os convidei pra gente montar um projeto de segunda-feira. Projeto esse que virou o Samba da Vela (CHAPINHA, 19/01/2009).

Em janeiro de 2002, a roda de samba que acontecia no bar da rua Dr. Antonio Bento, 257, passou a ser realizada na Casa de Cultura de Santo Amaro, localizada na Praça Francisco Ferreira Lopes, 434.

Como podemos notar nas falas dos entrevistados, o Samba da Vela surgiu em territórios não-institucionais. Foi no cotidiano de seus fundadores que essa manifestação se constituiu como fruto de experiência de vida.

O bar do Chapinha, quando da fundação do Samba da Vela, pode ser considerado como um dos territórios da cultura popular em Santo Amaro. Acreditamos que, mesmo quando a roda passou a ser realizada na Casa de Cultura (pertencente à Prefeitura Municipal de São Paulo), a identidade com a origem foi mantida. Nossa análise parte da fala dos entrevistados e dos registros que compõem os questionários, que comprovam que os fundadores e alguns dos antigos frequentadores são os mesmos. Para Chapinha (19/01/2009), apesar das naturais transformações, "tem que se manter fiel. Desde que a gente começou, mudaram algumas coisas, sabe? [...] Tudo muda. Mas a gente procura manter a verdadeira essência que é o samba."

A existência de um ritual para a realização da roda de samba constitui sua identidade e, ao mesmo tempo, uma particularidade dessa manifestação. Como em qualquer prática social semelhante, a roda tem uma espécie de "regulamento interno". Conforme Moura (2004), é inadmissível manejar um instrumento sem competência, falar mais alto do que o som que vem da roda ou interromper quem está puxando o samba. Essas regras são fundadas na amizade e na intimidade que a roda proporciona, no modo como as pessoas se relacionam etc. A hierarquia, na roda, é respeitada, não pelo sucesso ou pelo dinheiro que a pessoa tem, mas por seu conhecimento e história no samba.

O Samba da Vela não foge à regra. Paqüera (20/04/2009) explica que "se não fosse esse ritual, que se mantém vivo até hoje, da mesma forma que começou", possivelmente, não se conseguiria fortalecer essa expressão popular" que "valoriza a memória e firma a memória, crava como uma identidade, uma formação, uma filosofia de vida." 
Ali existe um caderno com a seleção das músicas cantadas na roda e três cores de velas que determinam esse processo de seleção, formando o "regulamento interno". Segundo Paqüera:

\begin{abstract}
Começou a aparecer muita música. A gente não conseguia guardar de uma semana para outra, porque cantava uma numa semana, na outra já esquecia. Tínhamos de ter um período para aprender a música, e aí sim passar para a outra. Montamos, então, um ritual: vela rosa durante duas a quatro semanas para quando o compositor mostra sua música inédita. [...] Passou esse período, vela azul. Canta tudo de novo. [...] Tudo para a gente memorizar. Acabaram esses dois processos, a diretoria - eu, Magno, Maurílio e o Chapinha - se reúne, analisa a música [...] e dá o seu aval. Aí fazemos um caderno com as músicas, distribuímos para a comunidade, e cantamos as músicas por dois meses (TACIOLI, 2008).
\end{abstract}

Paqüera aponta que "ritualizar" o Samba da Vela fez com que este se tornasse uma referência de samba, não só em São Paulo, mas no Brasil. Explica, ainda, que essa expressão sociocultural:

\footnotetext{
Forma novos laços de amizade e aí essa confraternização vai aumentando a gama de possibilidades e o círculo de amigos. Forma uma grande entidade, uma grande assembleia, uma grande comunidade. O nome comunidade aqui foi dado pelo povo. Não foi a gente que deu, era o Samba da Vela. As pessoas foram se unindo, se unindo, se unindo e acabou virando uma comunidade. É importante essa formação de dentro pra fora e voltar de fora pra dentro muito mais fortificada e mais embasada com o que já tem. No caso da fé, baseado na cruz. No caso da Vela, a vela é o referencial. Que vela que tá lá? É azul, é rosa, é branca? Pô, se for vela rosa, eu vou lá pra mostrar meu samba. (PAQÜERA, 20/04/2009).
}

Cada roda de samba, embora respeite estrutura e ritual específicos, além das características comuns do universo da cultura popular, é única e não se repete. Nela, há intimidade na forma como as pessoas se tratam e uma sensação de pertencimento, além de evidenciar que "o que é tradição dialoga com o presente no curso da história" (MOURA, 2004, p. 23).

Nesse espaço particular, o samba só termina quando a vela se apaga e todos cantam "Comunidade Chora", música de Magnu Sousá, Maurílio de Oliveira e Edvaldo Galdino. Encerrado o samba, o cozinheiro Oliveira serve a sopa que, conforme Maurílio, "é um ato de solidariedade". Chapinha (10/01/2009) explica que "tem muita gente que não vai embora enquanto não tomar a sopa."

\title{
São Paulo: "aqui a gente também tem bambas"
}


A cidade de São Paulo é comumente descrita como a "terra do trabalho" ou como a "locomotiva do Brasil". No entanto, São Paulo está repleta de manifestações e identidades culturais que diversificam sua paisagem urbana e humana. Diversidade esta que compõe os múltiplos territórios da metrópole paulistana e propõe que voltemos nosso olhar não somente aos aspectos políticos e econômicos que nela estão presentes, mas também às experiências socioculturais vivenciadas, cotidianamente, pelos seus tantos e tão diferentes sujeitos sociais. Nesse mesmo sentido, entendemos o lugar ocupado pelo Samba da Vela em Santo Amaro, ou seja, como um dos muitos territórios que constituem a cidade.

De acordo com Marcelino (2007), o modo como se apresentava a cidade de São Paulo no final do século XIX, com sua estrutura, rede de transportes e centralidade financeira e comercial, assinalava a metrópole que viria a ser em meados do século XX. Em trabalhos historiográficos sobre o município, é comum encontrarmos análises apontando que a cidade, na virada do século XIX para o XX, vivenciou um significativo crescimento populacional e urbano, vinculado à cafeicultura, à industrialização e, em grande parte, à imigração (especialmente italiana).

Ao mesmo tempo, o poder público buscava construir um novo formato para a cidade, seguindo os modelos europeus de urbanização e população. Com isso, procurava apagar as marcas da São Paulo de antes. A cidade deixava de ser um núcleo populacional "modesto", marcado por construções simples, para se tornar uma "nova cidade". Passou, portanto, a não ter mais uma vida considerada "desinteressante", para se transformar em uma cidade moderna ao estilo das cidades europeias (PORTO, 1992).

Contudo, como analisa Santos (1998), pensamos que essas concepções não apreendem a experiência social e cultural das camadas populares nacionais e suas manifestações na cidade, entre elas, o samba. A leitura de alguns estudiosos sobre o período assinala que, possivelmente, algumas cidades brasileiras (como São Paulo e Rio de Janeiro) vivenciavam um projeto de europeização no sentido arquitetônico, urbanístico e demográfico, com o intuito de suprimir espaços de vivências das camadas populacionais nacionais.

Lembremo-nos que, historicamente, as camadas populares foram tratadas à margem da sociedade e excluídas do processo de formação das cidades e, como nosso objeto de 
estudo está localizado em São Paulo, reforçamos essa exclusão, na cidade paulistana, pela máquina estatal e pelos grupos dominantes.

De acordo com Paoli e Duarte:

\begin{abstract}
Ao longo do século XX, intérpretes e analistas da Cidade de São Paulo apontaram insistentemente que sua trajetória de modernização, como de resto a de todas as grandes cidades do país, excluiu o reconhecimento dos diferentes espaços públicos de formação, informação e debate como parte fundamental do modo de integrar à cidadania vastas parcelas de sua população, sobretudo seus pobres. Embora correto, este reconhecimento da exclusão pública - e, portanto, da desigualdade social que permanece como traço constante e politicamente predatório da Cidade - tendeu também a passar a imagem das camadas populares como uma população passiva e homogênea, ao mesmo tempo vítima e ameaça potencial porque saída de um meio desinformado ou hostil, quando não frequentemente brutal. Uma gente, enfim, que passa ao largo da história da Cidade e aparece apenas na repetição e reprodução das próprias misérias e carências, já que até mesmo suas tradições e perspectivas de vida não poderiam qualificá-la para ser parceira da tarefa de construir uma Cidade moderna e civilizada (PAOLI; DUARTE, 2004, p. 53).
\end{abstract}

Pensamos o Samba da Vela como uma das muitas e diferentes manifestações da cultura popular brasileira que, como explica Chauí (1996, p21), "interage com a ideologia da cultura dominante em suas diferentes dimensões." Configura-se, assim, como uma forma de restituir e fortalecer a presença desse coletivo de sujeitos históricos na transformação social ativa.

Essas condições não resultaram em ausência de participação popular na construção e transformação de São Paulo. As classes menos favorecidas participavam (e participam) ao lidarem (e lidam) com a exclusão para sobreviver, manifestar-se culturalmente e interagir, mesmo que não da forma imposta e esperada pelos grupos no poder. As comunidades não estão rendidas ou prostradas diante da realidade que se apresenta. Resistem e lutam para preservar suas identidades, valendo-se de suas expressões e manifestações socioculturais, dentre elas, o samba, como estratégia de vivência, ferramenta de crítica, meio de fortalecimento de sua voz, tradução de sua realidade. Assim, o samba retrata a vida e a luta cotidiana dos sujeitos.

Paquera (20/04/2009), um dos fundadores e presidente do Samba da Vela, ressalta que "o cidadão tem a sua voz. Tá na hora das pessoas de fora, que estão no poder, começarem a abrir os olhos pra isso. É muito fácil abrir os olhos pro cofre público e não pro lado do povo. Mas, uma hora, aqui vai chegar lá." 
Portanto, defendemos a ideia de ser o Samba da Vela totalmente produzido por seus participantes, sem interferência direta da indústria cultural. O que não significa dizer, novamente, destacamos, que os participantes da roda de samba são pessoas isoladas das influências da indústria cultural. Todavia, acreditamos que a cultura popular reelabora os mecanismos de imposição social e cultural, de diferentes formas, em suas práticas cotidianas. Logo, compreendemos o Samba da Vela como uma manifestação da cultura popular em permanente processo de reelaboração cultural.

\section{Samba da Vela e cidadania}

A construção da cidadania, segundo Carvalho (2008, p. 9 e 10), se faz em três situações, a partir dos estudos de Marshall5: direitos civis - "fundamentais à vida, à liberdade, à propriedade, à igualdade perante a lei" (direitos religiosos, de liberdade de expressão, de garantia de ir e vir etc); direitos políticos - que asseguram a "participação do cidadão no governo da sociedade" (direito ao voto, à escolha partidária etc) ; direitos sociais - que garantem a participação do cidadão na distribuição da riqueza coletiva ( direitos previdenciários, à saúde, à assistência, à educação etc). Os direitos sociais permitem às sociedades politicamente organizadas reduzir os excessos de desigualdade produzidos pelo capitalismo e garantir um mínimo de bem-estar para todos. A ideia central em que esses direitos se baseiam é a de justiça social.

Contudo, entendemos a cidadania como direito à vida, em sua plenitude. Trata-se não apenas de atendimento às necessidades básicas, mas do acesso a todos os níveis de existência, a partir de uma construção coletiva. Logo, partimos da ampliação da ideia de direitos e de cidadania para além da perspectiva marshaliana.

Percebemos que as práticas culturais das comunidades "estiveram 'ausentes' dos discursos de uma sociedade 'administrada' por uma máquina gigantesca de controle total”. Contudo, em momentos como o que vivemos, há grupos que "ainda lutam para preservar a sua cultura" (SOUZA, 1997, p. 29), como acontece com o Samba da Vela.

\footnotetext{
${ }^{5}$ Marshall escreve sobre a conquista de direitos na Inglaterra. Neste país, a introdução de um direito parecia estar atrelada ao exercício pleno de outro, ou seja, foi exatamente o exercício dos direitos civis que fez com os ingleses reivindicassem direitos políticos e, então, sociais. José Murilo de Carvalho utiliza, como suporte teórico, os estudos de Marshall e traça uma análise comparativa entre Brasil e Inglaterra para discutir a cidadania (ou a incompletude da cidadania) no Brasil.
} 
Logo, consideramos a música como um importante espaço de reflexão sobre a realidade brasileira. Além disso, percebemos os participantes do Samba da Vela não como simples expectadores dos acontecimentos à sua volta, mas sujeitos de uma história que, somadas a outras, constituem e marcam sua identidade. Paralelamente, aqueles que vão apresentar e compartilhar seus sambas demonstram, em suas letras, sua visão de mundo, suas alegrias e frustrações, pois constroem e fortalecem as formas de ser da comunidade, criam vínculos, reforçam as noções e o sentimento de pertencimento, ao mesmo tempo que valorizam e fortalecem a cultura popular local.

Paqüera defende esse aspecto de modo muito contundente e verdadeiro, ao declarar que:

\begin{abstract}
Se você é um cidadão consciente, por isso a gente faz essa formação aqui (referindo-se ao Samba da Vela), essa formação vai fazer com que ninguém me controle porque eu tenho voz. Ninguém vai colocar um tapa-boca em mim porque eu tenho a minha voz, eu vou falar. E eu vou falar através do quê? De uma manifestação popular, que ela vai abranger todo mundo, todas as formas, todas as pessoas e chegar ao poder. Olha, o povo tá falando isso, isso e isso...preste atenção! (PAQÜERA, 20/04/2009).
\end{abstract}

Segundo Michel de Certeau (apud Cuche, 2002, p. 150), a cultura popular é construída no cotidiano, nas atividades "ao mesmo tempo banais e renovadas a cada dia". Nesse sentido, Ferreira (1997, p. 31) entende que a cultura popular se expressa no dia-adia, "no espaço e no tempo da cotidianidade das classes subalternas, nas suas condições de luta pela vida, através dos processos de adaptação e ressignificação dos quadros dados pelo sistema."

Outro conceito fundamental para pensarmos a importância da cultura na compreensão da dinâmica social é o de resistência sociocultural. A resistência é formada por expressões populares cotidianas (música, crença, formas de trabalho, alimentação e outros) resultantes das experiências de dominação e, especialmente, de recusa e (re)elaboração vivenciadas pelo povo.

A resistência parte de um desejo de emancipação, de autonomia. Logo, a cultura popular pode se configurar como um modo de resistência, quando a entendemos:

[...] como expressão dos dominados, buscando as formas pelas quais a cultura dominante é aceita, interiorizada, reproduzida e transformada, tanto quanto as formas pelas quais é recusada, negada e afastada, implícita ou explicitamente, pelos dominados (CHAUI, 1996, p. 24). 
Na mesma direção, estão as respostas dos questionários aplicados aos participantes do Samba da Vela. Estes o entendem como um instrumento de resistência sociocultural, pelos motivos abaixo elencados:

- "O Samba da Vela é um dos maiores movimentos de samba de nosso país."

- "Mesmo sem recursos financeiros, as pessoas estão sempre nesta roda de samba."

- "Pelo período em que está vivo. São oito anos fazendo samba."

- "Por possibilitar a reflexão sobre os problemas que estão em nossa sociedade e as respostas que podem ser dadas através dos sambas ali produzidos."

- "O Samba da Vela é uma forma de cultivar a cultura negra e dar oportunidade à comunidade de expressar seu modo de vida."

- "O Samba da Vela é um movimento de resistência porque seus objetivos, seus princípios e a forma como ele acontece são contra-hegemônicos. O que faz o Samba da Vela existir não é sua rentabilidade ou a busca por status, fama e poder de seus participantes. É uma construção coletiva em meio a tempos de relações individualistas. [...] É, assim como outras iniciativas, uma prova da qualidade da cultura local e da importância de sua manifestação como um discurso social para os membros que compõem essa comunidade e para o mundo que tem ouvidos atentos."

- "Por ser uma iniciativa espontânea e independente, sem objetivos comerciais."

- "Infelizmente, a distribuição de espaço e divulgação de cultura no Brasil é algo bastante desequilibrado, direcionado e induzido de forma a restarem opções 'afuniladas' de Cultura. Sendo assim, tudo o que não se insere no contexto comercial, fica inacessível ao grande público. O Samba da Vela é uma iniciativa que faz com que diversas manifestações culturais ainda sobrevivam, sem que haja a necessidade de inserção no contexto comercial."

- "Pelo apoio à cultura."

- "Em um mundo capitalista e voltado para a imagem (aparência), o Samba da Vela é voltado exclusivamente para a promoção do samba na sua forma mais pura e ainda está sempre lotado! Ou seja, é uma maneira de mostrar para o mundo que essa identidade brasileira é parte da vida dos cidadãos." 
- "Porque cantar, tocar e criar o samba tradicional é uma forma de resistência, uma vez que não é ouvido ou difundido nos meios de comunicação. Além disso, está presente o aspecto da formação do cidadão nesta roda."

- "Pelo fato de no Samba da Vela estar presente, aquele samba que veio de Angola, chegou na Bahia e foi para o Rio de Janeiro virar arte depois de muito preconceito e discriminação. Samba que parece não ter valor para a indústria da música. 0 Samba da Vela é uma forma de continuar aquela velha luta pelo espaço do samba."

- "Por ser um espaço que sobrevive numa cidade e num país que só valoriza o que a mídia dá espaço."

- "Por estarem todos unidos em favor da música, do samba e do que isso representa e transmite."

Destacamos, mais uma vez, a fala de Maurílio de Oliveira Souza, que defende o Samba da Vela como um instrumento de resistência sociocultural da seguinte forma:

É resistência à falta de caráter das pessoas que atrapalham o movimento, entende? Que nem aquele samba do Fundo de Quintal que fala assim: 'e fazem de tudo para silenciar a batucada dos nossos tantãs'. É uma resistência a isso, a todo tipo de escravidão, a todo tipo de diminuição do povo, das pessoas e, também, uma resistência ao apartheid (MAURILIO, 19/01/2009).

Cabe, aqui, refletirmos sobre o fato de nossa formação histórica ser marcada por processos de escravização e "negação do outro" e de sua alteridade. Processos estes que também ocorrem "no plano das representações e no imaginário social" (CANDAU, 2002, p.126). Nesta direção, o debate sobre cultura, especialmente, sobre a cultura popular, da maneira como adotamos neste trabalho, coloca-nos diante de sujeitos históricos e de instrumentos de resistência sociocultural por eles utilizados, afirmando suas identidades, ainda que em uma "situação de relações de poder assimétricas, de subordinação e acentuada exclusão".

\section{Considerações Finais}

A partir da revisão de literatura e da observação da cidade de São Paulo, considerando suas políticas públicas, a desigual distribuição dos equipamentos culturais, a falta de incentivo, reconhecimento e valorização da pluralidade de seus cidadãos e, por 
conseguinte, seus valores, expressões e modos de vida, pensamos quão longe estamos da sonhada justiça e igualdade sociais.

Contudo, ao ouvir os depoimentos de um dos músicos e de três fundadores do Samba da Vela, ao ler as contribuições dos participantes dessa roda de samba, registradas nos questionários por eles respondidos, ao presenciar as reuniões e os sambas ali apresentados, acreditamos, verdadeiramente, que, nas contradições e opressões do sistema, surgem caminhos para a transformação e ressignificação do que está posto.

Essas pessoas trazem, nas letras de seus sambas, a denúncia das injustiças que vivem, as ambiguidades de seu cotidiano, suas alegrias e conquistas, suas aspirações e interesses. Portanto, consideramos a importância do Samba da Vela quando este extrapola o entretenimento e o lazer, configurando-se como uma expressão das camadas populares pela transformação social, como instrumento de resistência sociocultural, lugar de uma fala coletiva, potencializador de debate e crítica e um importante meio de promoção do exercício da cidadania.

\section{Referências}

ALVES, Bernardo. A pré-história do samba. Petrolina: Edição do Autor, 2002.

BRASIL. Constituição Federativa do Brasil. Brasília: Senado Federal, 1988.

BRITTO, lêda Marques. Samba na cidade de São Paulo (1900-1930): um exercício de resistência cultural. Dissertação de Mestrado. São Paulo: USP, 1986.

CANDAU, Vera Maria Ferrão. Sociedade, Cotidiano Escolar e Cultura(s): Uma aproximação. 2002. Disponível em: <http://www.scielo.br/pdf/es/v23n79/10852.pdf>. Acesso em 24 jun. 2008.

CARVALHO, José Murilo de. Cidadania no Brasil: o longo caminho. Rio de Janeiro: Civilização Brasileira, 2008.

CHAUI, Marilena. Conformismo e resistência: aspectos da cultura popular no Brasil. São Paulo: Brasiliense, 1996.

CUCHE, Denys. A noção de cultura nas ciências sociais. Bauru: EDUSC, 2002.

FERREIRA, Maria Nazareth. Cultura Subalterna e o Neoliberalismo: a encruzilhada da América Latina. São Paulo: CELAC: ECA/USP, 1997.

LOPES, Nei. Partido-alto: Samba de bamba. Rio de Janeiro: Pallas, 2005. 
MARCELINO, Márcio Michalczuk. Uma leitura do samba rural ao samba urbano na cidade de São Paulo. Dissertação de mestrado. São Paulo: USP, 2007.

MARTINELLI, Maria Lúcia. "O Serviço Social na transição para o próximo milênio: desafios e perspectivas". In: Serviço Social \& Sociedade no 57. São Paulo: Cortez, 1998.

MOURA, Roberto M. No princípio, era a roda: um estudo sobre samba, partido-alto e outros pagodes. Rio de Janeiro: Rocco, 2004.

NAÇÕES UNIDAS NO BRASIL. Disponível em: <http://www.onubrasil. org.br/documentosdireitoshumanos>. Acesso em: 7 abr. 2008

NAPOLITANO, Marcos. A síncope das idéias: A questão da tradição na música popular brasileira. São Paulo: Fundação Perseu Abramo, 2007.

NAPOLITANO, Marcos \& WASSERMAN, Maria Clara. "Desde que o samba é samba: a questão das origens no debate historiográfico sobre a música popular brasileira". In: Revista Brasileira de História n³9. São Paulo: NPUH/Humanitas Publicações, 2000.

PAOLI, Maria Cecília \& DUARTE, Adriano. "São Paulo no plural: espaço público e redes de sociabilidade". In: PORTA, Paula (org.). História da Cidade de São Paulo v.3: a cidade na primeira metade do século XX. São Paulo: Paz e Terra, 2004.

PORTO, Antônio Rodrigues. História urbanística da cidade de São Paulo: 1554 a 1988. São Paulo: Carthago \& Forte, 1992.

SAMBA DA VELA. Disponível em: <http://www.sambadavela.com.br>. Acesso em: 18 mar.2008.

SANTOS, Carlos José Ferreira dos. Nem Tudo Era Italiano - São Paulo e pobreza (1890/1915). São Paulo: Annablume e FAPESP, 1998.

SOCIEDADE AMIGOS DA CULTURA AFRO-BRASILEIRA. Disponível em:

<http://www.amafro.org.br>. Acesso em: 03 jan. 2009.

SODRÉ, Muniz. Samba, o dono do corpo. Rio de Janeiro: Mauad, 1998.

SOUZA, Valmir de. "São Paulo: Diversidade Cultural e Discurso oficial". In: FARIA, Hamilton; SOUZA, Valmir de (orgs.). Cidadania Cultural: Leituras de uma política pública. São Paulo: Pólis, 1997.

TACIOLI, Ricardo. "Periferia do Rio e SP dividem palco de samba". In: Blogantidoto. 2008. Disponível em: <http://blogantidoto.blog.terra.com.br/page/2/>. Acesso em: 20 mar. 2009.

TINHORÃO, José Ramos. História social da música popular brasileira. São Paulo: Editora 34, 2005. 